\title{
ANALISIS FAKTOR-FAKTOR YANG MEMPENGARUHI MOTIVASI TENAGA KERJA INDONESIA UNTUK BEKERJA KE LUAR NEGERI (STUDI PADA CALON TENAGA KERJA INDONESIA DI KABUPATEN LOMBOK TIMUR, NTB)
}

\author{
Husniawati \\ Jurusan Pendidikan Ekonomi \\ Universitas Pendidikan Ganesha \\ Singaraja, Indonesia \\ e-mail: husnia18@gmail.com
}

\begin{abstract}
Abstrak
Penelitian ini bertujuan untuk mengetahui faktor-faktor yang mempengaruhi motivasi tenaga kerja Indonesia untuk bekerja ke luar negeri di Kabupaten Lombok Timur dan faktor yang paling dominan mempengaruhi motivasi tenaga kerja Indonesia untuk bekerja ke luar negeri di Kabupaten Lombok Timur. Jenis penelitian ini merupakan penelitian faktorial, dengan jumlah responden sebanyak 98 calon tenaga kerja Indonesia di Kabupaten Lombok Timur. Data dikumpulkan dengan menggunakan kuesioner dan dianalisis dengan analisis faktor melalui Statistical Program Social Scence (SPSS) 16.0 for windows. Hasil penelitian ini menunjukkan bahwa, terdapat empat faktor yang mempengaruhi motivasi tenaga kerja Indonesia untuk bekerja ke luar negeri di Kabupaten Lombok Timur, yaitu kebutuhan, harapan pribadi, kondisi ekonomi keluarga, dan kondisi lingkungan masyarakat. Besarnya variance explained masing-masing faktor tersebut secara berturut-turut, yaitu kebutuhan sebesar $53,584 \%$, harapan pribadi sebesar $30,069 \%$, kondisi ekonomi keluarga sebesar $11,551 \%$, dan kondisi lingkungan masyarakat sebesar $4,796 \%$. Faktor yang paling dominan mempengaruhi motivasi tenaga kerja Indonesia untuk bekerja ke luar negeri di Kabupaten Lombok Timur, yaitu kebutuhan dengan nilai variance explained $53,584 \%$, artinya total nilai variance explained dari kebutuhan mampu menjelaskan motivasi tenaga kerja Indonesia untuk bekerja ke luar negeri di Kabupaten Lombok Timur.
\end{abstract}

Kata Kunci: motivasi, tenaga kerja Indonesia, bekerja ke luar negeri

\begin{abstract}
This study aims to determine the factors that influence the motivation of Indonesia workers to work abroad in East Lombok Regency and the most dominant factors influence the motivation of Indonesia workers to work abroad in East Lombok Regency. This type of research is a factorial research, with the number of respondents as many as 98 candidates of Indonesia workers in East Lombok Regency. The data were collected by using questionnaire and analyzed by factor analysis using Statistical Program Social Scence (SPSS) 16.0 for windows. The results of this study indicate that there are four factors that influence the motivation of Indonesia workers to work in East Lombok Regency, namely their needs, personal expectation, family economic condition, and environmental condition. The amount of variance explained for each of these factors continuously is $53,584 \%$ for the need, $30,069 \%$ for personal expectations, $11,551 \%$ for family economic condition, and $4,796 \%$ for the condition of the community environment. The most dominant factor which influences the motivation of Indonesia workers to work abroad in East Lombok Regency is the need as many as $53,584 \%$ for the variance
\end{abstract}


explained, it means the total amount of variance explained of the need can explain the motivation of Indonesia workers to work abroad in East Lombok Regency.

\section{Keywords: motivation, Indonesia workers, working abroad}

\section{PENDAHULUAN}

Motivasi yang ada pada diri seseorang merupakan kekuatan pendorong yang menyebabkan seseorang tersebut melakukan suatu tindakan atau perbuatan untuk mencapai tujuan tertentu. Seseorang dikatakan memiliki motivasi tinggi jika seseorang tersebut memiliki tekad yang kuat untuk mencapai apa yang diinginkannya.

Mulyasa (2004:112) menjelaskan bahwa "motivasi adalah tenaga pendorong atau penarik yang menyebabkan adanya tingkah laku ke arah suatu tujuan tertentu". Menurut Sardiman (2011:73) bahwa "motivasi diartikan sebagai daya penggerak dari dalam diri subjek untuk melakukan aktivitas-aktivitas tertentu demi mencapai suatu tujuan". Kemudian Moekijat (2006:5) menyatakan bahwa "motivasi yaitu suatu daya pendorong atau perangsang untuk melakukan sesuatu". Pendapat lain dikemukakan oleh Arifin (dalam Wijono, 2010:21), mengungkapkan bahwa "motivasi adalah sebagai sesuatu yang bersumber dari dalam atau dari luar. la mempunyai tugas dan arah serta akan terus terjadi sehingga menghasilkan apa yang individu tersebut hayati. Proses ini akan terus berjalan sebagai satu perputaran di dalam perilaku seseorang". Sedangkan menurut Kamus Besar Bahasa Indonesia (2008:10) bahwa "motivasi adalah dorongan yang timbul pada diri seseorang sadar atau tidak sadar untuk melakukan suatu tindakan dengan tujuan tertentu, atau usaha-usaha yang dapat menyebabkan seseorang atau sekelompok orang tertentu bergerak melakukan sesuatu karena ingin mencapai tujuan yang dikhendaki".

Mc.Donald (dalam Sardiman, 2011) menyatakan bahwa motivasi mengandung beberapa elemen penting, yaitu motivasi mengawali terjadinya perubahan energi pada diri setiap individu manusia, motivasi ditandai dengan munculnya rasa atau feeling, afeksi dan emosi yang dapat menentukan tingkah lagu manusia, dan motivasi akan dirangsang karena adanya tujuan. Jadi perkembangan motivasi akan membawa perubahan energi di dalam sistem "neurophysiological" yang ada pada organisme manusia. Karena menyangkut perubahan energi manusia (walaupun motivasi itu muncul dari dalam diri manusia), penampakannya akan menyangkut kegiatan fisik manusia, selain itu motivasi dalam hal ini sebenarnya merupakan respons dari suatu aksi, yakni tujuan.

Menurut Oemar (2010) bahwa terdapat beberapa fungsi motivasi, yaitu mendorong timbulnya suatu tindakan atau perbuatan karena tanpa adanya motivasi dalam diri seseorang maka tidak akan timbul suatu perbuatan seperti bekerja, motivasi berfungsi sebagai pengarah, artinya mengarahkan perbuatan ke pencapaian tujuan yang diinginkan, dan motivasi berfungsi sebagai penggerak. Motivasi berfungsi sebagai mesin dalam mobil. Besar kecilnya motivasi menentukan cepat lambatnya suatu pekerjaan. Sardiman (2011) juga mengemukakan bahwa fungsi motivasi terdiri dari beberapa fungsi, yaitu sebagai berikut: mendorong manusia untuk berbuat, jadi sebagai penggerak atau motor yang melepaskan energi, menentukan arah perbuatan, yakni ke arah tujuan yang hendak dicapai sesuai dengan rumusan tujuannya, dan menyeleksi perbuatan, menentukan perbuatan-perbuatan apa yang harus dikerjakan yang serasi guna mencapai tujuan, dengan menyisihkan perbuatan-perbuatan yang tidak bermanfaat bagi tujuan tersebut.

Berbicara tentang macam atau jenis motivasi ini dapat dilihat dari berbagai sudut pandang. Menurut Sardiman (2011) macam-macam motivasi dapat diklasifikasikan menjadi beberapa jenis, yaitu motif-motif bawaan, motif bawaan adalah motif yang dibawa sejak lahir, jadi motivasi itu tanpa dipelajari. Sebagai contoh misalnya: dorongan untuk makan, minum, bekerja, beristirahat, dan dorongan seksual. Selanjutnya, motif-motif yang dipelajari, motif yang dipelajari yaitu motif- 
motif yang timbul karena dipelajari. Misalnya dorongan untuk belajar suatu cabang ilmu pengetahuan, dan dorongan untuk mengajar sesuatu di dalam masyarakat. Motif ini seringkali disebut dengan motif yang diisyaratkan secara sosial. Kemudian, motivasi jasmaniah seperti rileks, insting otomatis, napas, dan sebagainya dan yang terakhir yaitu motivasi rohaniah seperti kemauan atau minat.

$$
\text { Frandsen (dalam Sardiman, }
$$
2011:87) membagi motivasi menjadi beberapa jenis, yaitu Cognitif Motives, motif ini menyangkut gejala intrinsik, yakni menyangkut kepuasan individual. Kepuasan individual yang berada di dalam diri manusia biasanya berwujud proses dan produk mental. Selanjutnya, selfexpression, penampilan diri adalah sebagian dari perilaku manusia, dalam hal ini seseorang mempunyai atau memiliki keinginan aktualisasi diri. Kemudian, Selfenhancement yaitu dimana melalui aktualisasi diri dan pengembangan kompetensi akan meningkatkan kemajuan diri seseorang. Ketinggian dan kemajuan diri ini menjadi salah satu keinginan bagi setiap individu.

Sedangkan menurut Woodworth dan Marquis (dalam Sardiman, 2011:88) juga membagi motivasi menjadi beberapa jenis, yaitu motif atau kebutuhan organis, misalnya: kebutuhan untuk minum, makan, bernapas, seksual, berbuat, dan kebutuhan untuk beristirahat. Kemudian, motif-motif darurat, misalnya: dorongan untuk menyelamatkan diri, dorongan untuk membalas, untuk berusaha, untuk memburu. Jelasnya motivasi jenis ini timbul karena rangsangan dari luar; dan selanjutnya, motif-motif objektif. Dalam hal ini menyangkut kebutuhan untuk melakukan eksplorasi, melakukan manipulasi. Motifmotif ini muncul karena dorongan untuk dapat menghadapi dunia luar secara efektif. Motivasi digunakan sebagai penggerak atau pendorong seseorang untuk malakukan suatu kegiatan tertentu guna mencapai tujuan yang dikehendaki, misalnya mengapa seseorang memilih menekuni suatu bidang tertentu atau bersedia melakukan jenis kegiatan atau pekerjaan tertentu. Di Kabupaten Lombok Timur, program kesempatan kerja ke luar negeri yang di adakan oleh pemerintah banyak diikuti oleh masyarakat di daerah tersebut. Hal ini menunjukkan bahwa Kabupaten Lombok Timur merupakan daerah yang potensial sebagai asal tenaga kerja Indonesia. Pada umumnya timbulnya motivasi seseorang untuk bekerja di luar negeri didasarkan pada perbandingan untung rugi yang berkaitan dengan kedua tempat tersebut. Selain itu, tujuan utama diadakannya program kesempatan kerja di luar negeri yaitu untuk meningkatkan taraf hidup migran dan keluarganya, sehingga umumnya mereka mencari pekerjaan yang dapat memberikan pendapatan dan status sosial yang lebih tinggi di negara tujuan (Tjiptoherijanto, 2000). Motivasi seseorang untuk bekerja di luar negeri juga di tentukan oleh banyak faktor. Uno (2011) menyebutkan bahwa motivasi seseorang untuk bekerja ke luar negeri dipengaruhi oleh dua faktor yaitu faktor intrinsik dan ekstrinsik.

Faktor intrinsik merupakan faktorfaktor yang terdapat di dalam diri individu itu sendiri. Dalam hal ini faktor intrinsik dibagi menjadi dua yaitu kebutuhan dan harapan pribadi. Kebutuhan merupakan segala sesuatu yang dibutuhkan manusia untuk mempertahankan hidup serta untuk memperoleh kesejahteraan dan kenyamanan. Setiap individu memiliki beragam kebutuhan, untuk dapat memenuhi kebutuhannya, individu cendrung akan bertindak untuk melakukan suatu pekerjaan yang dapat menghasilkan sesuatu berupa uang. Kebutuhan seseorang biasanya berbanding sejajar dengan motivasi, semakin besar kebutuhan seseorang untuk dipenuhi maka semakin besar pula motivasi yang dimiliki oleh seseorang tersebut untuk bekerja. Sehubungan dengan banyaknya kebutuhan yang harus dipenuhi oleh masyarakat Lombok Timur, maka semakin besar pula motivasi yang dimiliki oleh masyarakat tersebut untuk bekerja. Tetapi tingginya motivasi kerja yang di miliki masyarakat Lombok Timur tidak didukung dengan ketersediaan lapangan pekerjaan yang luas di daerah tersebut, sehingga menyebabkan banyak masyarakat Lombok Timur mengambil keputusan untuk bekerja ke luar negeri. Dimana di negara tujuan tersebut 
banyak tersedia kesempatan kerja dengan upah yang tinggi, sehingga besar harapan untuk dapat memenuhi semua kebutuhan dirinya dan juga keluarganya.

Harapan dalam kehidupan manusia sebagai bentuk cita-cita, atau keinginan supaya sesuatu itu terjadi. harapan adalah keadaan mental positif pada seseorang dengan kemampuan yang dimilikinya dalam upaya mencapai tujuan pada masa depan. Uno (2011:48) menjelaskan bahwa "harapan adalah suatu kekuatan atas kepercayaan individu bahwa kegiatankegiatan tertentu akan membawa hasil tertentu". Sedangakan menurut Lopez (2009:487) "harapan merupakan tenaga positif yang mendorong seseorang untuk bekerja melalui keadaan yang sulit". Selanjutnya Carr (2004:90) mengatakan bahwa "harapan adalah kemampuan untuk merencanakan jalan keluar dalam upaya mencapai tujuan walaupun adanya rintangan, dan menjadikan motivasi sebagai suatu cara dalam mencapai tujuan". Jadi secara umum seseorang termotivasi untuk melakukan sesuatu jika dirinya percaya bahwa tingkah lakunya tersebut mendatangkan hasil. Seseorang tersebut kemudian percaya bahwa hasil tersebut mempunyai nilai positif bagi dirinya. Misalnya di Kabupaten Lombok Timur banyak masyarakat memilih untuk mengambil keputusan bekerja di luar negeri dengan harapan dapat meningkatkan perekonomian keluarganya. Karena di negara tujuan tersebut lebih memberikan banyak peluang pekerjaan dengan tingkat upah yang jauh lebih tinggi dibandingkan dengan tingkat upah di daerah asal.

Faktor ekstrinsik yaitu faktor-faktor yang berasal dari lingkungan luar dan dapat mempengaruhi motivasi Tenaga Kerja Indonesia (TKI) untuk bekerja ke luar negeri. Faktor eksternal tersebut meliputi kondisi ekonomi keluarga dan kondisi lingkungan masyarakat.

Kondisi ekonomi adalah keadaan atau kenyataan yang terlihat oleh indera manusia tentang kemampuan seseorang dalam memenuhi kebutuhannya. Kondisi ekonomi seseorang dalam kehidupan sehari-hari dihadapkan pada dua hal yang saling berhubungan yaitu adanya sumbersumber penghasilan yang dimiliki yang sifatnya terbatas yang akan digunakan untuk membiayai atau memenuhi kebutuhan yang tidak terbatas baik jumlah maupun kualitasnya. Secara umum, kondisi sosial ekonomi setiap orang itu berbedabeda dan bertingkat, ada yang keadaan sosial ekonominya menengah ke atas, menengah, dan menengah ke bawah. Di Kabupaten Lombok Timur, sebagian besar masyarakatnya berada pada tingkat ekonomi menengah dan menengah ke bawah. Pada keluarga dalam katagori miskin, biasanya tidak memiliki aset yang dapat dijual, serta tidak memiliki jaringan untuk meminjam uang, dan kehilangan pekerjaan merupakan ancaman bagi kelangsungan hidup keluarganya. Ada beberapa bidang pekerjaan yang digeluti sebagian besar masyarakat Lombok timur diantaranya yaitu pertanian, perkebunan, pertambangan, perdagangan, nelayan, buruh, dan lain sebagainya. Jenis pekerjaan yang digeluti masyarakat Lombok Timur sangat berpengaruh terhadap pendapatannya. Masyarakat Lombok Timur yang memiliki pendapatan rendah sangat berdampak terhadap ketidakmampuan untuk memenuhi kebutuhannya sendiri dan juga keluarganya. Sehingga masyarakat Lombok Timur yang memiliki pendapatan rendah atas hasil kerjanya akan mencari solusi lain untuk mengatasi permasalahannya tersebut.

Lingkungan masyarakat merupakan bagian ruang lingkup individu dalam melakukan interaksi dan sosialisasi, dan berpengaruh terhadap motivasi individu dalam melakukan suatu aktivitas. Pengaruh itu terjadi karena keberadaan individu tersebut dalam masyarakat. Seperti misalnya seseorang yang tinggal di daerah yang terdapat banyak mantan TKI atau calon TKI atau sering bergaul dengan mantan TKI yang telah berhasil akan mempengaruhi motivasi individu tersebut untuk menjadi TKI di luar negeri. Faktor lingkungan masyarakat yang mempengaruhi motivasi individu untuk bekerja di luar negeri yaitu kegiatan individu dalam masyarakat, teman bergaul dan bentuk kehidupan masyarakat. 
Namun, menjadi tenaga kerja Indonesia diluar negeri bukanlah tanpa hambatan, banyak tenaga kerja Indonesia yang dideportasi oleh pemerintah negara tujuan, seperti di Malaysia dan Arab Saudi terutama tenaga kerja ilegal. Selain itu, banyak juga tenaga kerja Indonesia yang menjadi korban kekerasan oleh majikannya, namun tidak menjadi efek jera bagi masyarakat Kabupaten Lombok Timur menjadi tenaga kerja Indonesia di luar negeri.

Meninjau dari permasalahan yang ada maka perlu dilakukan penelitian untuk mengetahui faktor-faktor yang mempengaruhi motivasi tenaga kerja Indonesia untuk bekerja ke luar negeri di Kabupaten Lombok Timur, dan untuk mengetahui faktor yang paling dominan mempengaruhi motivasi tenaga kerja Indonesia untuk bekerja ke luar negeri di Kabupaten Lombok Timur

Manfaat dari penelitian ini yaitu: manfaat teoritis, hasil penelitian ini diharapkan dapat menambah pengetahuan tentang faktor-faktor yang mempengaruhi motivasi tenaga kerja Indonesia untuk bekerja ke luar negeri di Kabupaten Lombok Timur; dan manfaat praktisnya yaitu, penelitian ini diharapkan dapat memberikan masukan kepada pemerintah baik di tingkat pusat maupun daerah dalam merancang kebijakan yang terkait dengan masalah ketenagakerjaan di Indonesia, dan hasil penelitian ini juga diharapkan dapat menambah kepustakaan skripsi, serta dapat dipergunakan oleh mahasiswa sebagai sumber refrensi.

\section{METODE}

Penelitian ini merupakan penelitian faktorial. Adapun faktor yang diduga mempengaruhi motivasi Tenaga Kerja Indonesia (TKI) untuk bekerja ke luar negeri adalah (1) faktor intrinsik yang meliputi kebutuhan dan harapan pribadi; (2) faktor ekstrinsik yang meliputi kondisi ekonomi keluarga dan kondisi lingkungan masyarakat. Dari hasil penelitian ini diharapkan diperoleh faktor-faktor yang mempengaruhi motivasi Tenaga Kerja Indonesia untuk bekerja ke luar negeri dan faktor yang paling dominan mempengaruhi motivasi Tenaga Kerja Indonesia untuk bekerja ke luar negeri. Penelitian ini dilakukan di Kabupaten Lombok Timur, Nusa Tenggara Barat.

Dalam pengumpulan

dan

menganalisa suatu data, langkah pertama yang sangat penting adalah menentukan populasi terlebih dahulu. Menurut Sugiyono (2010) bahwa populasi adalah wilayah generalisasi yang terdiri atas subjek atau objek yang mempunyai kualitas dan karakteristik tertentu yang ditetapkan oleh peneliti untuk dipelajari dan kemudian ditarik kesimpulannya. Berdasarkan pengertian populasi di atas, maka yang menjadi populasi dalam penelitian adalah masyarakat yang mendaftarkan diri secara resmi sebagai calon Tenaga Kerja Indonesia di Dinas Tenaga Kerja dan Transmigrasi Kabupaten Lombok Timur. Menurut sumber Dinas Tenaga Kerja dan Transmigrasi Kabupaten Lombok Timur bahwa data calon tenaga kerja Indonesia pada bulan September-November tahun 2017 adalah berjumlah 4.215 jiwa (Dinas Tenaga Kerja dan Transmigrasi Kabupaten Lombok Timur, 2017).

Dalam penelitian ini tidak mungkin semua populasi dapat diteliti, hal ini disebabkan oleh beberapa faktor, diantaranya keterbatasan biaya, keterbatasan tenaga, dan keterbatasan waktu yang tersedia. Maka penelitian diperkenankan mengambil sebagian objek populasi yang telah ditentukan, dengan catatan bagian yang diambil tersebut mewakili bagian lain yang diteliti. Selanjutnya, untuk menentukan besarnya ukuran sampel dari populasi dapat digunakan rumus pendekatan Slovin sebagai berikut Umar, 2010: 146).

$$
n=\frac{N}{1+N e^{2}}
$$

keterangan:

$n=u k u r a n$ sampel, $N=$ ukuran populasi, $e^{2}=$ eror/persen kelonggaran ketidaktelitian karena kesalahan pengambilan sampel yang diinginkan.

Sampel yang digunakan dalam penelitian ini sebanyak 98 responden. Teknik pengambilan sampel pada penelitian ini yaitu dengan menggunakan incidental sampling. Incidental Sampling adalah penentuan sampel dengan mengambil 
responden yang kebetulan ada atau tersedia di suatu tempat sesuai dengan konteks penelitian. Kriteria yang digunakan dalam penelitian ini yaitu masyarakat yang mendaftarkan diri secara resmi sebagai calon Tenaga Kerja Indonesia di Dinas Tenaga Kerja dan Transmigrasi Kabupaten Lombok Timur.

Dalam melakukan penelitian, pengumpulan data dilakukan dengan metode kuesioner atau angket. Kuesioner merupakan teknik pengumpulan data yang dilakukan dengan cara memberi seperangkat pertanyaan atau pernyataan tertulis kepada responden untuk dijawabnya (Sugiyono, 2010). Kuesioner digunakan untuk memperoleh data-data kualitatif mengenai faktor-faktor yang mempengaruhi motivasi Tenaga Kerja Indonesia untuk bekerja ke luar negeri di Kabupaten Lombok Timur. Kuesioner dalam penelitian ini disebarkan kepada 98 responden yang merupakan calon tenaga kerja Indonesia yang telah terdaftar secara resmi di Dinas Tenaga Kerja dan Transmigrasi kabupaten Lombok Timur. Jenis data yang digunakan dalam penelitian ini adalah data kualitatif. Data kualitatif dalam penelitian ini berupa data yang diperoleh dari responden calon tenaga kerja Indonesia mengenai motivasi tenaga kerja Indonesia untuk bekerja ke luar negeri di Kabupaten Lombok Timur. Sumber data yang digunakan dalam penelitian ini yaitu, data primer yang diperoleh dari responden secara langsung melalui kuesioner yang diisi sendiri oleh responden yang dijadikan sampel penelitian. Kategori penskoran kuesioner faktor kebutuhan, faktor harapan pribadi, faktor kondisi ekonomi keluarga, dan faktor kondisi lingkungan masyarakat dalam mempengaruhi motivasi tenaga kerja Indonesia untuk bekerja ke luar negeri dengan menggunkanan skala likert. Skala likert digunakan untuk mengukur sikap, pendapat dan persepsi seseorang atau sekelompok orang tentang fenomena sosial (Sugiyono, 2010). Pengukuran variabel menggunakan skala likert dengan lima alternatif jawaban, masing-masing diberi skor, yaitu skor 5 = sangat setuju (SS), skor 4 = setuju (S), skor $3=$ kurang setuju, skor 2 = tidak setuju (TS), dan skor 1 = sangat tidak setuju (STS).
Kuesioner sebagai instrumen pengumpulan data ordinal yang merupakan penjabaran dari indikator variabel. Sebelum digunakan untuk pengumpulan data di lapangan, terlebih dahulu harus diuji tingkat validitas dan reliabilitasnya. Dalam menguji validitas kuesioner dilakukan perhitungan korelasi antara masing-masing pernyataan dengan skor total dengan menggunakan rumus teknik korelasi product moment. Instrumen penelitian dikatakan valid apabila koefisien kolerasi antar butir lebih besar dari $r_{\text {-tabel }}=0,361$ dengan tingkat kesalahan alpha 0,05 (Sugiyono, 2010). Untuk membantu proses pengolahan data secara cepat dan tepat, maka pengelolaan data uji validitas dapat dilakukan dengan program SPSS 16.0 for windows. Reliabilitas menunjuk pada suatu pengertian bahwa suatu instrumen cukup dapat dipercaya untuk digunakan sebagai alat pengumpulan data karena instrumen tersebut sudah baik. Menurut Arikunto (2006), instrumen yang sudah dipercaya atau yang reliabel akan menghasilkan data yang dapat dipercaya juga. Dalam penelitian ini, untuk menguji reliabilitas instrumennya menggunakan rumus Alpha Cronbach. Pengujian statistik dengan menggunakan teknik statistik Alpha cronbach, instrumen dikatakan reliabel untuk mengukur variabel apabila memiliki nilai alpha lebih besar dari 0,60. Dalam penelitian ini, untuk menguji reliabilitas instrumen digunakan bantuan komputer yaitu SPSS 16.0 for windows.

Teknik analisis data yang digunakan dalam penelitian ini adalah analisis faktor. Analisis faktor digunakan untuk menganalisis faktor yang mempengaruhi motivasi Tenaga Kerja Indonesia untuk bekerja ke luar negeri di Kabupaten Lombok Timur. Pengujian hipotesis dilakukan dengan menggunakan Statistical Program Social Scence (SPSS) 16.0 for Windows dengan menggunakan factor analysis.

\section{HASIL DAN PEMBAHASAN Hasil}

Data yang berhasil dikumpulkan dari kuesioner yang disebarkan dan setelah diolah dengan SPSS 16.0 for windows menunjukkan faktor-faktor yang mempengaruhi motivasi tenaga kerja 
Indonesia untuk bekerja ke luar negeri di Kabupaten Lombok Timur dapat dijelaskan oleh persentase dari masing-masing faktor. Nilai total Variance Explained digunakan untuk mengetahui persentase dari empat faktor yang dianalisis. Hasil analisis faktor melalui SPSS menunjukkan persentase dari masing-masing faktor dapat dilihat pada tabel berikut.

Tabel 1. Total Variance Explained

Extraction Sums of Squared Rotation Sums of Squared

\begin{tabular}{|c|c|c|c|c|c|c|c|c|c|}
\hline \multirow[b]{2}{*}{$\begin{array}{l}\text { Com } \\
\text { pone } \\
\text { nt }\end{array}$} & \multicolumn{3}{|c|}{ Initial Eigenvalues } & \multicolumn{3}{|c|}{ Loadings } & \multicolumn{3}{|c|}{ Loadings } \\
\hline & Total & $\begin{array}{c}\% \text { of } \\
\text { Varianc } \\
e\end{array}$ & $\underset{\%}{\text { Cumulative }}$ & Total & $\begin{array}{c}\% \text { of } \\
\text { Varianc } \\
e\end{array}$ & $\begin{array}{c}\text { Cumulative } \\
\%\end{array}$ & Total & $\begin{array}{c}\% \text { of } \\
\text { Variance }\end{array}$ & $\begin{array}{c}\text { Cumulative } \\
\%\end{array}$ \\
\hline 1 & 2.143 & 53.584 & 53.584 & 2.143 & 53.584 & 53.584 & 1.812 & 45.302 & 45.302 \\
\hline 2 & 1.203 & 30.069 & 83.653 & 1.203 & 30.069 & 83.653 & 1.534 & 38.351 & 83.653 \\
\hline 3 & .462 & 11.551 & 95.204 & & & & & & \\
\hline 4 & .192 & 4.796 & 100.000 & & & & & & \\
\hline
\end{tabular}

Berdasarkan tabel 1 dapat dilihat bahwa, faktor kebutuhan memiliki eigenvalue sebesar 2,143 dengan nilai varian sebesar $53,584 \%$, faktor harapan pribadi memiliki eigenvalue sebesar 1,203 dengan nilai varian sebesar 30,069\%, faktor kondisi ekonomi keluarga memiliki eigenvalue sebesar 0,462 dengan nilai varian sebesar $11,551 \%$, dan faktor lingkungan masyarakat memiliki eigenvalue sebesar 0,192 dengan nilai varian sebesar $4,796 \%$,

Untuk menjelaskan motivasi tenaga kerja Indonesia untuk bekerja keluar negeri di kabupaen Lombok Timur, dapat dilakukan dengan ekstraksi faktor. Ekstraksi faktor dapat dijelaskan oleh total persentase dari masing-masing faktor utama. Faktor-faktor utama tersebut adalah faktor kebutuhan dan faktor harapan pribadi yang memiliki nilai parameter eigenvalue > 1. Untuk mengetahui distribusi dimensidimensi yang belum dirotasi ke dalam faktor yang telah terbentuk maka dapat dilihat pada output SPSS 16.0 (Rotated Component Matrix). Faktor yang mampu menjelaskan motivasi tenaga kerja Indonesia untuk bekerja keluar negeri di kabupaen Lombok Timur, dapat dilihat pada tabel 2 berikut.

Tabel 2. Faktor yang menjelaskan motivasi tenaga kerja Indonesia unuk bekerja keluar negeri di kabupaten Lombok Timur

\begin{tabular}{lccc}
\hline \multicolumn{1}{c}{ Faktor } & Eigenvalue & $\begin{array}{c}\text { Variance } \\
\text { Explained (\%) }\end{array}$ & Factor Loading \\
\hline Kebutuhan & 2,143 & 53,584 & 0,937 \\
Harapan Pribadi & 1,203 & 30,069 & 0,936 \\
Kondisi Ekonomi Keluarga & 0,462 & 11,551 & 0,895 \\
Kondisi Lingkungan Masyarakat & 0,192 & 4,796 & 0,837 \\
\hline
\end{tabular}

Berdasarkan Tabel 2 di atas, dapat dijelaskan bahwa faktor yang memiliki eigenvalue $>1$ adalah fakor kebutuhan dan harapan pribadi, total nilai varianced explained dari kedua faktor keseluruhan mampu menjelaskan sebesar 83,653\%. Dengan demikian $83,653 \%$ dari seluruh variabel yang ada, dapat dijelaskan oleh

dua faktor yang terbentuk. Faktor
kebutuhan memiliki variance explained $53,584 \%$, artinya bahwa faktor kebutuhan mampu mempengaruhi motivasi tenaga kerja Indonesia untuk bekerja ke luar negeri sebesar $53,584 \%$. Faktor harapan pribadi memiliki variance explained 30,069\%, artinya bahwa faktor harapan pribadi 
mempengaruhi motivasi tenaga kerja Indonesia untuk bekerja ke luar negeri sebesar 30,069\%

Menentukan nama faktor yang telah terbentuk untuk masing-masing faktor bersifat subjektif, kadangkala variabel yang memiliki nilai faktor loading tertinggi digunakan untuk memberi nama faktor. Untuk melihat nilai faktor loading dapat dilihat pada tabel 3 berikut.

Tabel 3. Rotated Component Matrix

\begin{tabular}{|c|c|c|}
\hline \multirow{2}{*}{ Faktor } & \multicolumn{2}{|c|}{ Component } \\
\hline & 1 & 2 \\
\hline Kebutuhan & .937 & .149 \\
\hline Harapan Pribadi & .936 & .101 \\
\hline Kondisi Ekonomi Keluarga & .014 & .895 \\
\hline Kondisi Lingkungan Masyarakat & .241 & .837 \\
\hline
\end{tabular}

Berdasarkan tabel 3 diatas, faktor yang mempengaruhi motivasi tenaga kerja Indonesia untuk bekerja ke luar negeri dapat dikelompokkan menjadi 2 (dua) faktor. Faktor satu terbentuk dari faktor kebutuhan dengan faktor loading sebesar 0,937, dan faktor harapan pribadi dengan faktor loading sebesar 0,936 . Faktor dua terbentuk dari faktor kondisi ekonomi keluarga dengan faktor loading sebesar 0,895, dan faktor kondisi lingkungan masyarakat dengan faktor loading sebesar 0,837 .
Kemudian untuk menentukan dimensi atau faktor yang paling dominan mempengaruhi motivasi tenaga kerja Indonesia untuk bekerja keluar negeri di kabupaen Lombok Timur, digunakan parameter koefisien varimax atau mendekati 1 atau -1 . Nilai yang mendekati 1 diawali oleh nilai 0,50 sedangkan nilai yang mendekati -1 diawali oleh $-0,50$. Secara lebih rinci hasil ringkasan rotasi dari matriks faktor memuat nilai varimax rotation, dapat dilihat pada tabel 4 berikut.

Tabel 4. Matriks Rotasi Hasil Anallisis Faktor

Dimensi atau faktor motivasi tenaga kerja
Indonesia untuk bekerja ke luar negeri

Kebutuhan

Harapan Pribadi

Berdasarkan tabel 4, maka faktor yang paling dominan mempengaruhi motivasi tenaga kerja Indonesia untuk bekerja ke luar negeri di Kabupaten Lombok Timur adalah faktor kebutuhan dengan nilai varimax rotation $53,584 \%$. Artinya kejelasan dari dimensi atau faktor motivasi tenaga kerja Indonesia untuk bekerja ke luar negeri di Kabupaten Lombok Timur adalah kebutuhan yang paling mendominasi sebesar 53,584 \%.

\section{Pembahasan}

Motivasi tenaga kerja Indonesia untuk bekerja ke luar negeri di Kabupaten Lombok Timur di pengaruhi oleh faktor

\begin{tabular}{ll}
\multicolumn{3}{c}{ Varimax Rotation (\%) } \\
$(2)$ & $(4)$ \\
53,584 & - \\
- & 30,069 \\
\hline
\end{tabular}

kebutuhan, harapan pribadi, kondisi ekonomi keluarga, dan kondisi lingkungan masyarakat. Hal ini sesuai dengan teori yang dinyatakan oleh Uno (2011), bahwa faktor yang mempengaruhi motivasi tenaga kerja Indonesia untuk bekerja ke luar negeri adalah kebutuhan, harapan pribadi, kondisi ekonomi keluarga, dan kondisi lingkungan masyarakat. Dengan demikian, untuk menjelaskan faktor yang mempengaruhi motivasi tenaga kerja Indonesia untuk bekerja ke luar negeri di Kabupaten Lombok Timur, dapat dilihat dari faktorfaktor yang memiliki eigenvalue > 1 yaitu, faktor kebutuhan, dan harapan pribadi. 
Faktor kebutuhan, dan harapan pribadi merupakan faktor yang dominan mempengaruhi motivasi tenaga kerja Indonesia untuk bekerja ke luar negeri di Kabupaten Lombok Timur. Dari ke dua faktor tersebut, faktor yang paling dominan mempengaruhi motivasi tenaga kerja Indonesia untuk bekerja ke luar negeri di Kabupaten Lombok Timur adalah faktor kebutuhan. Faktor ini paling dominan dibandingkan faktor-faktor yang lain disebabkan karena kebutuhan merupakan segala sesuatu yang harus dipenuhi oleh manusia agar mampu mempertahankan hidup serta untuk memperoleh kesejahteraan dan kenyamanan. Setiap individu memiliki beragam kebutuhan, untuk dapat memenuhi kebutuhannya, individu cendrung akan bertindak untuk melakukan suatu pekerjaan yang dapat menghasilkan sesuatu berupa uang. Kebutuhan seseorang biasanya berbanding sejajar dengan motivasi, semakin besar kebutuhan seseorang untuk dipenuhi maka semakin besar pula motivasi yang dimiliki oleh seseorang tersebut untuk bekerja. Sehubungan dengan banyaknya kebutuhan yang harus dipenuhi oleh masyarakat Kabupaten Lombok Timur, maka semakin besar pula motivasi yang dimiliki oleh masyarakat tersebut untuk bekerja. Tetapi Tingginya motivasi kerja yang dimiliki masyarakat Kabupaten Lombok Timur tidak didukung dengan ketersediaan lapangan pekerjaan yang luas di daerah tersebut, sehingga menyebabkan banyak masyarakat mengambil keputusan untuk bekerja ke luar negeri. Hasil penelitian ini sejalan dengan teori Uno (2011), kebutuhan meliputi kebutuhan fisik, kebutuhan keamanan, dan kebutuhan sosial. Ketiga indikator tersebut adalah hal penting dalam menentukan motivasi tenaga kerja Indonesia untuk bekerja ke luar negeri di Kabupatenn Lombok Timur.

Harapan pribadi merupakan faktor yang dominan mempengaruhi motivasi tenaga kerja Indonesia untuk bekerja ke luar negeri di Kabupaten Lombok Timur karena harapan dalam kehidupan manusia sebagai bentuk cita-cita, atau keinginan supaya sesuatu itu terjadi. Harapan juga merupakan suatu bentuk kekuatan atas kepercayaan individu bahwa kegiatan- kegiatan tertentu akan membawa hasil tertentu, dan menjadikan motivasi sebagai suatu cara dalam mencapai tujuan pada masa depan. Jadi secara umum seseorang termotivasi untuk melakukan sesuatu jika dirinya percaya bahwa tingkah lakunya tersebut mendatangkan hasil. Seseorang tersebut kemudian percaya bahwa hasil tersebut mempunyai nilai positif bagi dirinya. Misalnya, masyarakat di Kabupaten Lombok Timur banyak memilih untuk mengambil keputusan bekerja ke luar negeri dengan harapan mendapatkan pekerjaan yang cocok, dan upah yang tinggi sehingga bisa meningkatkan perekonomian keluarganya. Hasil penelitian ini sejalan dengan teori Uno (2011), harapan pribadi sangat berpengaruh terhadap motivasi tenaga kerja Indonesia untuk bekerja ke luar negeri di Kabupaten Lombok Timur.

\section{SIMPULAN DAN SARAN Simpulan}

Berdasarkan hasil analisis data dan pembahasan, maka dapat ditarik simpulan yaitu: faktor-faktor yang mempengaruhi motivasi tenaga kerja Indonesia untuk bekerja ke luar negeri di Kabupaten Lombok Timur adalah faktor kebutuhan dengan nilai variance sebesar 53,584 \%, faktor harapan pribadi dengan nilai variance sebesar 30,069 \%, faktor kondisi ekonomi keluarga dengan nilai variance sebesar $11,551 \%$, dan faktor kondisi lingkungan masyarakat dengan nilai variance sebesar $4,796 \%$; faktor yang paling dominan mempengaruhi motivasi tenaga kerja Indonesia untuk bekerja ke luar negeri di Kabupaten Lombok Timur adalah faktor kebutuhan dengan nilai varimax rotation $53,584 \%$.

\section{Saran}

Berdasarkan pembahasan dan kesimpulan di atas, maka dapat diajukan beberapa saran yaitu: bagi pemerintah Kabupaten Lombok Timur. Pemerintah diharapkan untuk terus meningkatkan pelatihan kerja bagi calon tenaga kerja Indonesia sesuai dengan bidang keahliannya atau pekerjaan yang akan di dapatkan di negara tujuan, sehingga kualitas kerja yang dihasilkan di negara 
tujuan maksimal. Selain itu, pemerintah juga diharapkan untuk membekali dan mengembangkan kemampuan berkomunikasi dalam bahasa negara tujuan bagi calon tenaga Indonesia; pemerintah diharapkan untuk mengembangkan padat karya dan melakukan kerjasama dengan industri-industri kecil lainnya, sehingga dapat menyerap banyak tenaga kerja dari masyarakat di daerah tersebut; pemerintah diharapkan untuk terus meningkatkan kualitas pendidikan masyarakat baik melalui jalur formal maupun informal supaya pada masa mendatang tenaga kerja Indonesia di Kabupaten Lombok Timur dapat bersaing dengan tenaga kerja dari daerah lain atau bahkan dari negara lain, serta bisa mendapatkan pekerjaan yang berkualitas. Bagi para calon Tenaga Kerja Indonesia (TKI) yang akan bekerja ke luar negeri di daerah Kabupaten Lombok Timur diharapakan saat pulang kembali ke kampung halamannya sudah dapat menggeluti atau menekuni suatu bidang pekerjaan yang bisa mendatangkan hasil yang menguntungkan baik bagi dirinya dan juga keluarganya berbekal dari pengalaman kerja saat di luar negeri. Bagi Peneliti lain yang berminat mendalami mengenai faktorfaktor yang mempengaruhi motivasi tenaga kerja Indonesia untuk bekerja ke luar negeri diharapkan melakukan penelitian lebih lanjut dengan menggunakan faktor-faktor yang lainnya. Hal ini berguna untuk dapat membandingkan faktor-faktor yang mempengaruhi motivasi tenaga kerja Indonesia untuk bekerja ke luar negeri di daerah yang satu dengan daerah yang lainnya.

\section{DAFTAR PUSTAKA}

Arikunto, Suharsimi. 2006. Prosedur Penelitian Suatu Pendekatan Praktik. Jakarta: Rineka Cipta.

Carr, Alan. 2004. Positive Psychologi, The Science of Happines and Human Strength. New York: BrunnerRoutledge.

Kamus Besar Bahasa Indonesia Cetakan Ketiga. 2008. Jakarta: Balai Pustaka.
Lopez, J. 2009. Positive Psychological Assessment. Washington, DC, US: American Psychological Associatiation.

Moekijat. 2006. Dasar-Dasar Motivasi. Bandung: CV Pionir Jaya.

Mulyasa. 2004. Manajemen Berbasis Sekolah. Bandung: PT Remaja Rosdakarya.

Oemar, Hamalik. 2010. Proses Belajar Mengajar. Jakarta: PT. Bumi Aksara

Sardiman, A.M. 2011. Interaksi dan Motivasi Belajar Mengajar. Jakarta: PT Raja Grafindo Persada

Sugiyono. 2010. Metode Penelitian Pendidikan (Pendekatan Kuantitatif, Kualitatif, dan R\&D). Bandung: ALFABETA.

Tjiptoherijanto, Priyono. 2000. Demografi. Jakarta: Departemen Pendidikan dan Kebudayaan.

Umar, Husen. 2010. Riset Pemasaran dan bisnis. Jakarta: PT. Gramedia Pustaka Utama.

Uno, B. Hamzah 2011. Teori Motivasi dan pengukurannya. Jakarta: PT Bumi Aksara.

Wijono, Sutarto. 2012. Psikologi Industri dan Organisasi (Dalam Suatu Bidang Gerak Psikologi Sumber Daya Manusia). Jakarta: Kencana Prenada Media Group. 